\title{
RUMAH PELANGI: EVOLUSI PERSEPSI MELALUI HIBURAN
}

\author{
Nabila Rahmani ${ }^{1)}$, Franky Liauw ${ }^{2)}$ \\ 1) Program Studi S1 Arsitektur, Fakultas Teknik, Universitas Tarumanagara, nabila.rahmani@hotmail.com \\ 2) Program Studi S1 Arsitektur, Fakultas Teknik, Universitas Tarumanagara, frankyl@ft.untar.ac.id
}

\begin{abstract}
Abstrak
Dengan bertumbuh besar dalam zaman globalisasi, milenial mempunyai tingkat toleransi dan pemikiran terbuka terhadap isu-isu tertentu. Hal ini telah menciptakan diskusi terhadap komunitas LGBT yang telah meningkat dalam dekade terakhir. Walaupun hal tersebut sudah diterima di berbagai negara, di Indonesia masih dianggap tabu dan tidak benar. Tidak banyak dari kaum mereka yang mengekspresikan diri di Indonesia dikarenakan opini masyarakat yang buruk tetapi sudah mulai muncul beberapa dari mereka di Indonesia. Proyek tersebut bertujuan untuk meningkatkan kesadaran dan mendidik warga negara Indonesia terhadap komunitas LGBT. Sebuah angket yang diisi oleh 95 orang telah menunjukkan bahwa banyak milenial dan generasi muda yang mempunyai tingkat toleransi yang tinggi terhadap komunitas LGBT. Proyek tersebut menggunakan metode perancangan fenomenologi yang dibantu dengan sebuah narasi. Dengan metode desain berdasarkan sebuah alur cerita, konsep labirin telah diciptakan.
\end{abstract}

Kata kunci: kesadaran; LGBT; milenial, toleransi

\begin{abstract}
As millennials grow in the age of globalisation they are more open minded and have a higher tolerance towards certain issues. This has sparked discussions towards the LGBT community which has greatly increased this past decade. Although it's widely accepted around the world, it's still considered taboo in Indonesia. Not many in the country express themselves as part of the community due to the strong opinions towards them, there are quite a handful in Indonesia. This project is aimed to raise awareness and educate the people in Indonesia about the LGBT community. A survey filled by 95 people has shown that a lot of millennials and the young generations have a higher tolerance towards the LGBT community. This project uses the phenomenology method backed with a narrative. With the method being used a design based on the flow of a plot from a narrative, the maze concept was created.
\end{abstract}

Keywords: awareness; LGBT; millennials; tolerance

\section{PENDAHULUAN}

Milenial adalah generasi yang sedang mengambil alih dunia. Generasi ini tidak bisa lepas dari penggunaan teknologi, terutama internet, karena hal itu telah menjadi kebutuhan pokok yang membantu mereka berkomunikasi dan mendapatkan ilmu tentang berbagai budaya di seluruh dunia. Dengan itu, mereka dikenal sebagai generasi yang lebih toleran dan terbuka dibandingkan dengan generasi lain. Pertumbuhan dalam toleransi mereka ini bisa dihubungkan dengan karenanya generasi yang bertumbuh besar di dunia yang lebih beragam.

Toleransi adalah salah satu sikap yang saling menghormati dan saling bekerjasama di antara kelompok-kelompok masyarakat yang berbeda secara budaya, bahasa, etnis, budaya, politik dan agama. Nilai kerjasama telah menciptakan toleransi terhadap topik-topik yang generasi sebelumnya tidak akan setuju, seperti LGBT (Lesbian, Gay, Bisexual, Transgender). Dengan keterbukaan millennials yang makin meningkat, komunitas LGBT pun makin meningkat karena mereka lebih mempunyai kebebasan untuk beropini dan merasa lebih diterima dan dihormati yang lain.Tingkat toleransi tersebut juga meningkat di Indonesia, dimana masyarakat lebih terbuka terhadap kaum LGBT, sehingga banyak dari kita yang juga mulai berani mengekspresikan diri sebagai kaum mereka. Walaupun banyak millennials yang sudah mulai lebih menerima dan terbuka terhadap kaum mereka, masih banyak yang belum karena faktor- 
faktor seperti agama dan edukasi, maka dibutuhkan sebuah program yang bisa membuka pikiran dan meningkatkan kesadaran masyarakat untuk lebih terbuka terhadap komunitas mereka.

\section{KAJIAN LITERATUR}

\section{Toleransi}

Toleransi mengacu pada keterampilan yang kita butuhkan untuk menjalani hidup bersama dengan damai. la menciptakan sebuah masyarakat dimana orang bisa merasa dihargai dan dihormati, tidak hanya itu, toleransi juga merupakan aspek yang penting untuk masyarakat yang sehat dan layak ditinggali (Waraich, Al Hakam, 2018). Sifat tersebut adalah faktor esensi untuk perdamaian (Frey, 2018). Sifat dan sikap tersebut harus kita tunjukkan kepada semua orang walaupun berbeda etnis, agama, budaya, ras, dan sebagainya dengan memperhatikan prinsipprinsip yang dipegang sendiri, tanpa mengorbankan prinsip-prinsip tersebut, karena hal tersebut akan berdampak positif bagi integritas bangsa dan masyarakat pada umumnya. Dengan ketidakadaan sikap toleransi, akan memicu konflik yang tidak diharapkan.

\section{Komunitas LGBT}

LGBT atau Lesbian, Gay, Bisexual, Transgender adalah salah satu kelompok minoritas yang banyak meningkat dalam generasi millennial. Istilah tersebut mulai tercatat sekitar tahun 1990an dan sudah dikenal dan atau diakui oleh banyak negara. Mereka bisa dikelompokkan sebagai komunitas yang bukan heterosexual atau mempunyai orientasi seksual kepada jenis kelamin yang sama. Sebagian besar gerakan mereka mengatasnamakan HAM (Hak Asasi Manusia) (Kristianto, 2017).

Banyak orang yang menganggap bahwa kaum LGBT adalah hal yang negative, dimana mereka dilihat sebagai orang yang mempunyai kegangguan mental, sehingga mereka mengancam masyarakat dan nilai moralnya dan pranata keluarga tradisional. Ada juga yang melihatnya sebagai hal positif, dimana mereka menunjukkan pentingnya keluarga dan memberikan model lain mengenai bagaimana sebuah keluarga penuh dengan kasih sayang dan juga sebagai cara untuk mengendalikan populasi (Cathy, 2018)

\section{Milenial dan komunitas LGBT}

Milenial adalah generasi yang mempunyai kebebasan dan percaya diri dalam mengekpresikan diri secara publik lebih besar dibandingkan generasi-generasi sebelumnya, sehingga banyak dari generasi ini yang mengaku bahwa mereka adalah bagian kaum LGBT. Mereka telah meningkatkan populasi kaum LGBT. Karena tingkat penerimaan pada kaum LGBT, mereka merasa lebih aman untuk mengekspresikan diri sebagai kaum LGBT. Hal ini berhubungan lagi dengan tingkat toleransi milenial yang tinggi terhadap isu-isu tertentu.

Generasi millennial yang mengaku sebagai bagian dari kaum LGBT lebih banyak dibandingkan generasi-generasi sebelumnya. Mereka yang mengaku sebagai kaum LGBT akan lebih toleran kepada kaum mereka sendiri dibandingkan dengan orang heteroseksual kepada heteroseksual, karena pengalaman melewati masalah yang sama. Mereka juga akan lebih mendukung anak mereka jika mereka mengaku sebagai LGBT dibandingkan generasi lain.

\section{METODE}

Data opini masyarakat terhadap isu tersebut akan didapatkan dengan melalukan angket yang disebarkan secara digital dan juga langsung pada wilayah Jakarta. Data yang akan dikumpulkan dalam angket tersebut adalah umur, agama, orientasi seksual dan keterbukaan peserta pada isu LGBT. Data tersebut akan digunakan untuk melihat tingkat toleransi terhadap komunitas LGBT di Indonesia. Hasil dari angket tersebut akan membantu perancangan yang akan menggunakan metode phenomenology dengan dukungan naratif, dengan phenomenology secara dasar konsep rancangan yang didukung dengan sebuah narasi terhadap tema yang dipilih. 


\section{DISKUSI DAN HASIL}

Berikut adalah hasil angket yang penulis laksanakan dengan 95 peserta:
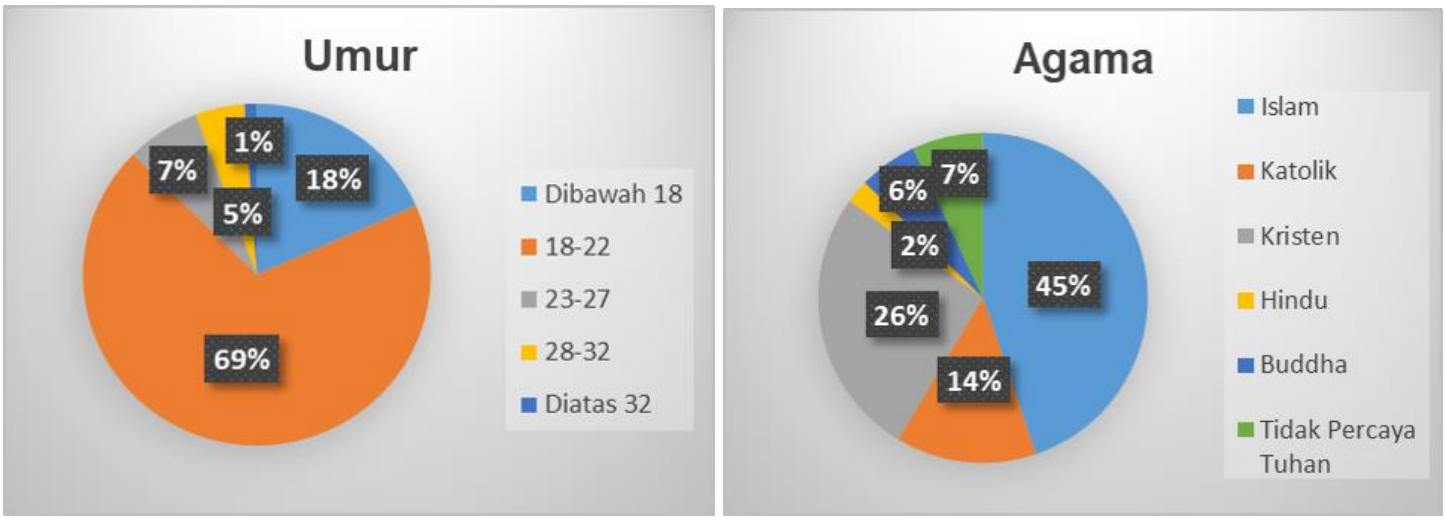

Gambar 1. Pie Chart Hasil Survey Berdasarkan Umur dan Agama
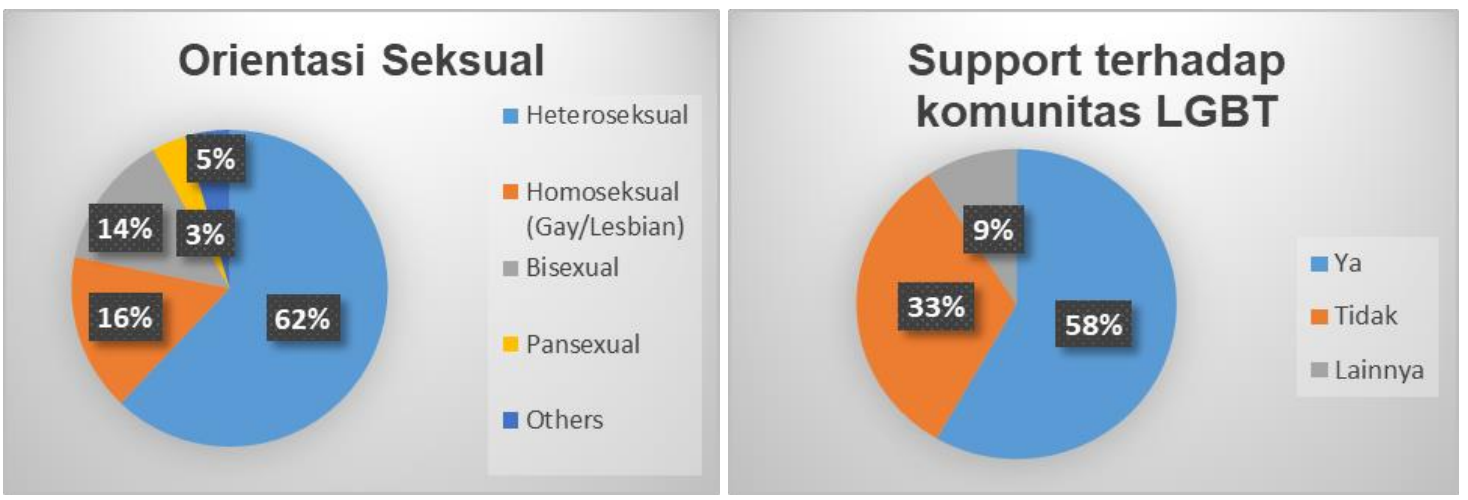

Gambar 2. Pie Chart Hasil Survey Berdasarkan Orientasi Seksual dan

Dukungan Terhadap Komunitas LGBT

Dari data diatas bisa disimpulkan bahwa banyak yang sudah mempunyai toleransi dan menerima komunitas LGBT. Bisa dikatakan bahwa masyarakat Indonesia masih enggan dengan komunitas LGBT tetapi mereka mempunyai potensi untuk lebih menerima dan belajar tentang komunitas LGBT. Berikut adalah rincian program ruang yang akan dibutuhkan dalam proyek tersebut: 
Tabel 1. Program Ruang

\begin{tabular}{|c|c|c|c|c|c|}
\hline Zoning & Ruang & Kegiatan & $\begin{array}{l}\text { Kapasitas } \\
\text { (orang) }\end{array}$ & $\begin{array}{l}\text { Jumlah } \\
\text { ruang } \\
\text { (buah) }\end{array}$ & Luas $\left(\mathrm{m}^{2}\right)$ \\
\hline \multirow{4}{*}{$\begin{array}{l}\text { Cognitive } \\
\text { Learning } \\
\text { Area }\end{array}$} & Photo room & $\begin{array}{l}\text { Tempat foto-foto yang merupakan tempat-tempat } \\
\text { bertemu kaum LGBT }\end{array}$ & 32 & 1 & 150 \\
\hline & Music room & $\begin{array}{l}\text { Music performance yang menunjukkan penyanyi } \\
\text { LGBT \& lagu-lagu tentang LGBT }\end{array}$ & 42 & 1 & 80 \\
\hline & $\begin{array}{l}\text { Guessing } \\
\text { room }\end{array}$ & $\begin{array}{l}\text { Permainan dimana pengunjung menebak } \\
\text { kepribadian orang lain }\end{array}$ & 42 & 1 & 90 \\
\hline & Tasting room & $\begin{array}{l}\text { Pengunjung dapat mencoba makanan yang dibuat } \\
\text { oleh komunitas LGBT }\end{array}$ & 38 & 1 & 80 \\
\hline \multirow{4}{*}{$\begin{array}{l}\text { Affective } \\
\text { Learning } \\
\text { Area }\end{array}$} & Theatre room & $\begin{array}{l}\text { Aktivitas teater dengan tema dan cerita tentang } \\
\text { LGBT }\end{array}$ & 42 & 1 & 90 \\
\hline & $\begin{array}{l}\text { Audio/Visual } \\
\text { room }\end{array}$ & $\begin{array}{l}\text { Pengunjung akan menonton sebuah video pendek } \\
\text { dengan tema LGBT, lalu akan diminta untuk } \\
\text { memberi pendapatnya yang akan mengantarnya ke } \\
\text { ruang yang lain }\end{array}$ & 33 & 3 & $\begin{array}{c}50 \times 3= \\
150\end{array}$ \\
\hline & $\begin{array}{l}\text { Vulneribility } \\
\text { room }\end{array}$ & $\begin{array}{l}\text { Pengunjung akan diberi suasana yang tidak enak } \\
\text { untuk merasakan kesulitan para komunitas LGBT } \\
\text { dalam mengekspresikan diri }\end{array}$ & 32 & 1 & 50 \\
\hline & Learning Halls & $\begin{array}{l}\text { Pengunjung akan diberikan informasi tentang } \\
\text { komunitas LGBT di lorong-lorong yang mengarahkan } \\
\text { mereka ke ruang-ruang lainnya }\end{array}$ & 20 & 8 & $\begin{array}{c}40 \times 8= \\
320\end{array}$ \\
\hline \multirow{6}{*}{$\begin{array}{l}\text { Psycho- } \\
\text { motor } \\
\text { Learning } \\
\text { Area }\end{array}$} & $\begin{array}{l}\text { Charades } \\
\text { room }\end{array}$ & $\begin{array}{l}\text { Pengunjung akan melawan tim lain dalam } \\
\text { permainan tebak kata }\end{array}$ & 34 & 1 & 50 \\
\hline & $\begin{array}{l}\text { Video Game } \\
\text { room }\end{array}$ & $\begin{array}{l}\text { Pengunjung akan melawan tim/orang lain melalui } \\
\text { video game }\end{array}$ & 34 & 1 & 50 \\
\hline & $\begin{array}{l}\text { Team Building } \\
\text { room }\end{array}$ & $\begin{array}{l}\text { Pengunjung akan melaksanakan beberapa team } \\
\text { building games }\end{array}$ & 36 & 2 & 130 \\
\hline & $\begin{array}{l}\text { Truth or Dare } \\
\text { room }\end{array}$ & $\begin{array}{l}\text { Pengunjung akan diminta untuk sebuah game kecil } \\
\text { dimana yang kalah harus melakukan truth or dare } \\
\text { dengan tema yang berhubungan dengan LGBT }\end{array}$ & 34 & 1 & 60 \\
\hline & VR Room & $\begin{array}{l}\text { Pengunjung akan melewati simulasi dimana dia bisa } \\
\text { memilih untuk membantu orang yang di komunitas } \\
\text { LGBT atau tidak, lalu akan diarahkan ke ruangan lain } \\
\text { sesuai dengan pilihannya }\end{array}$ & 34 & 1 & 80 \\
\hline & Trivia Room & $\begin{array}{l}\text { Pengunjung akan melawan tim lain dalam sebuah } \\
\text { trivia dengan topik yang berhubungan dengan LGBT }\end{array}$ & 34 & 1 & 60 \\
\hline $\begin{array}{l}\text { Final } \\
\text { Meeting } \\
\text { Area }\end{array}$ & $\begin{array}{l}\text { Dance \& } \\
\text { Game room }\end{array}$ & $\begin{array}{l}\text { Pengunjung dapat memakan, bermain, berkumpul, } \\
\text { menonton dan juga ikut serta dalam dance } \\
\text { performance sebagai ruang terakhir maze tersebut, } \\
\text { dimana aktivitas dan pilihan yang mereka } \\
\text { laksanakan dalam maze akan memberikan mereka } \\
\text { benefit tertentu }\end{array}$ & 300 & 1 & 450 \\
\hline $\begin{array}{l}\text { Public } \\
\text { Area }\end{array}$ & Lobby & Mendaftarkan diri, menunggu & 50 & 1 & 80 \\
\hline $\begin{array}{l}\text { Private } \\
\text { Area }\end{array}$ & $\begin{array}{l}\text { Administratio } \\
\text { n room }\end{array}$ & Ruang mengelola aktivitas bangunan & 6 & 1 & 35 \\
\hline Private \& & Staff Room & Tempat untuk beristirahat, makan & 20 & 1 & 50 \\
\hline $\begin{array}{l}\text { Service } \\
\text { Area }\end{array}$ & $\begin{array}{l}\text { Women's } \\
\text { bathroom }\end{array}$ & Buang air kecil, buang air besar & 4 & 5 & $\begin{array}{c}15 \times 4= \\
60\end{array}$ \\
\hline $\begin{array}{l}\text { Service } \\
\text { Area }\end{array}$ & $\begin{array}{l}\text { Men's } \\
\text { bathroom }\end{array}$ & Buang air kecil, buang air besar & 4 & 5 & $\begin{array}{c}15 \times 4= \\
60\end{array}$ \\
\hline & $\begin{array}{l}\text { Staff } \\
\text { bathroom }\end{array}$ & Buang air kecil, buang air besar, ganti baju & 4 & 2 & $\begin{array}{c}15 \times 2= \\
30\end{array}$ \\
\hline
\end{tabular}


Berikut merupakan hasil rancangan untuk proyek tersebut:

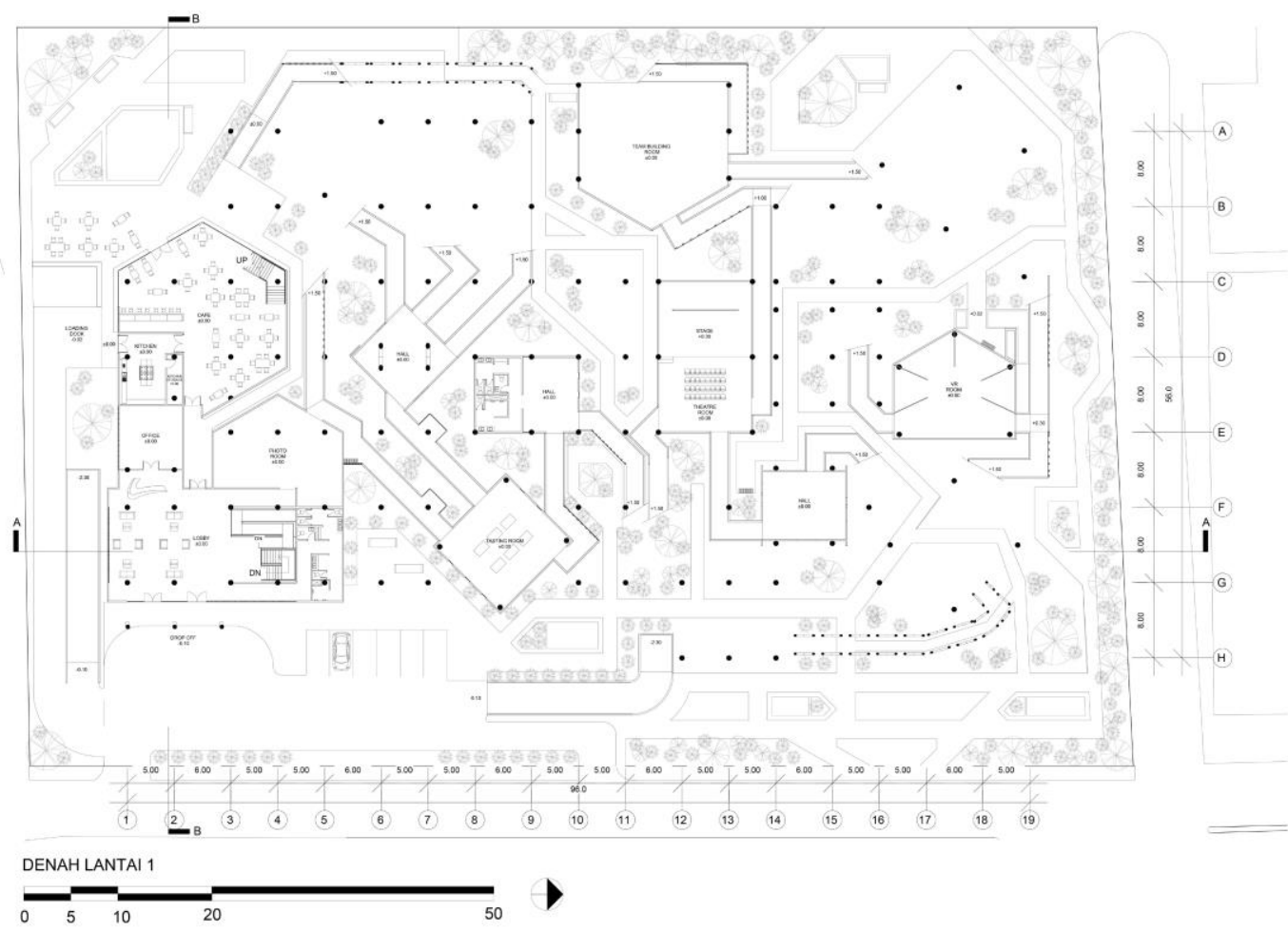

Gambar 3. Denah Lantai Dasar Sumber: Penulis, 2019

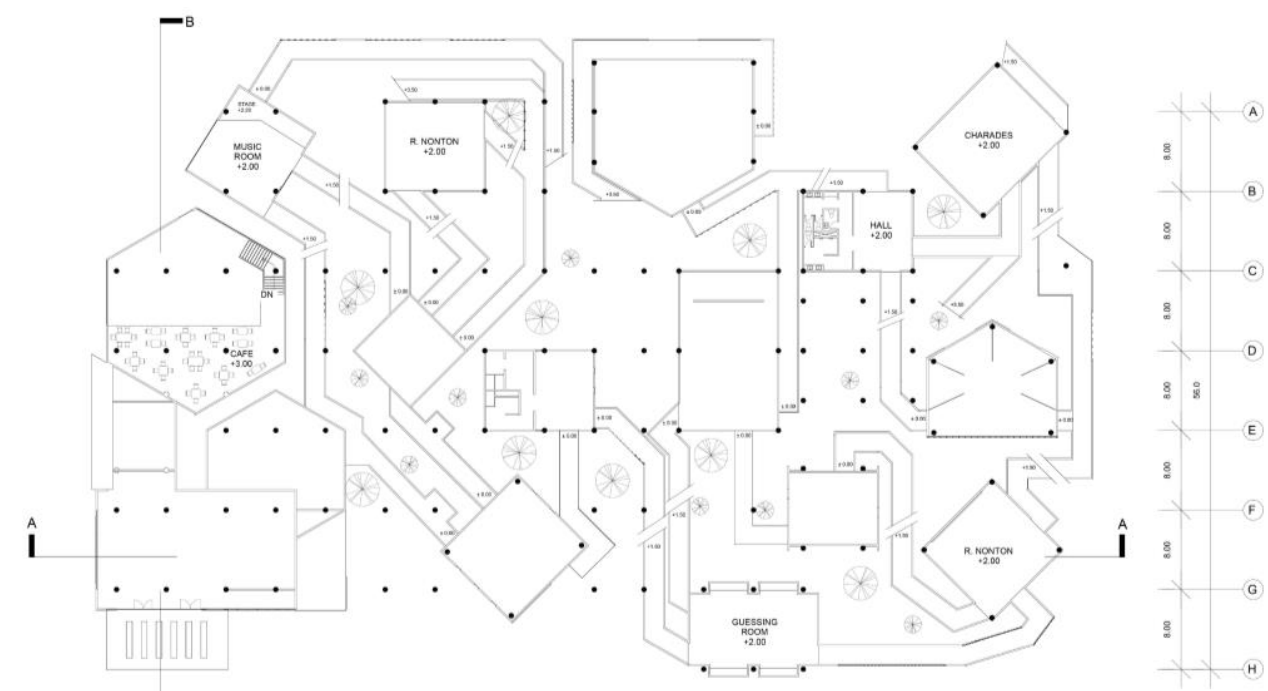

- в

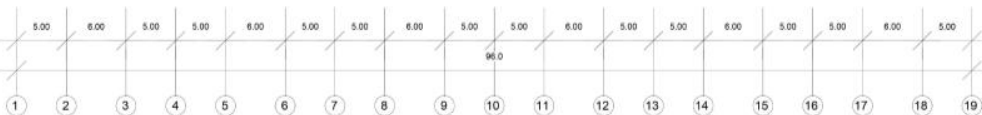

DENAH LANTAI 1M

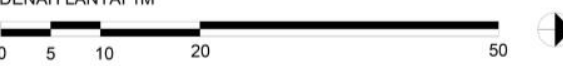

Gambar 4. Denah Lantai 1

Sumber: Penulis, 2019 


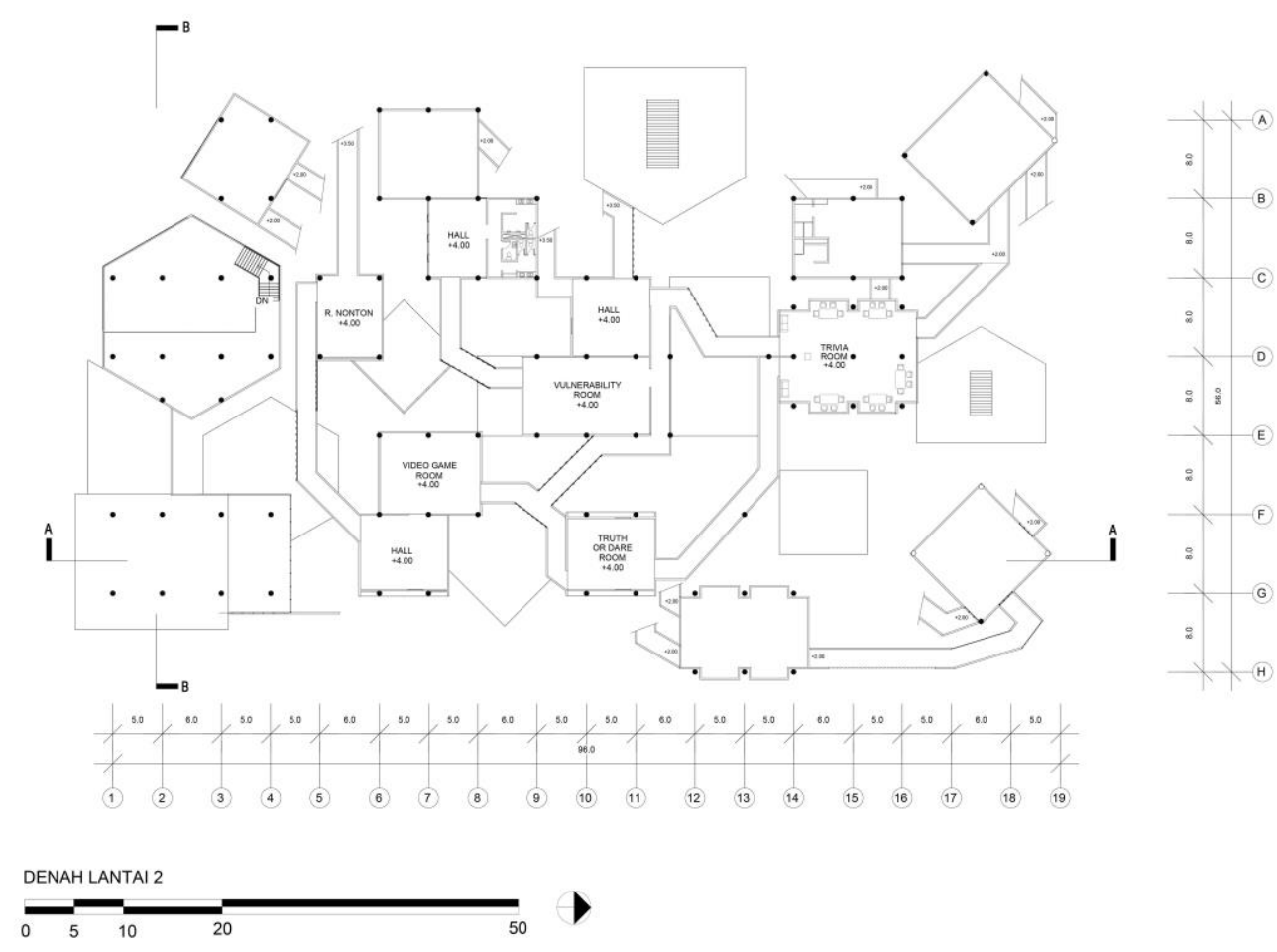

Gambar 5. Denah Lantai 2

Sumber: Penulis, 2019

\section{KESIMPULAN DAN SARAN}

Setelah menganalisa isu terpilih, maka terdapat kesimpulan sebagai berikut:

a. Proyek tersebut merupakan salah satu solusi yang bisa dimunculkan dari masalah keterbukaan masyarakat terhadap komunitas LGBT.

b. Proyek tersebut termasuk proyek yang mempunyai resiko yang tinggi dikarenakan isu yang berhubungan dengan proyek tersebut.

c. Masih banyak warga Indonesia yang tidak terbuka dan sadar akan kaum LGBT walaupun mulai banyak yang sudah muncul.

d. Banyak kaum LGBT yang sudah mulai muncul di Indonesia tetapi tidak terbuka dikarenakan takut dengan opini dan tanggapan masyarakat kepada kaum mereka.

Saran pada proyek ini diberikan kepada masyarakat untuk lebih terbuka dalam menerima ideologi-ideologi baru yang tidak biasanya diajarkan dalam sekolah dan untuk saling menghormati satu sama lain, walaupun berbeda opini.

\section{REFERENSI}

Cathy J. Cohen, M. F. (2018). Millennial Attitudes on LGBT Issues: Race, Identity and Experience. University of Chicago.

Frey, W. H. (2018). The Millennial Generation: A Demographic Bridge to America's Diverse Future. Metropolitan Policy Program.

Kristianto, D. (2017). Konsepsi Lesbian Gay Bisexual dan Transgender (LGBT) - Perspektif Jaringan Islam Liberal (JIL).

Waraich, J. A. (2018, April 13). Tolerance - Its Importance in Social Life. Retrieved from The Weekly Al-Hakam: http://www.alhakam.org/tolerance-its-importance-social-life 